\title{
A PREDOMINANTLY FOREIGN-BORN OR FOREIGN-TRAINED WORKFORCE: ONE HOSPITAL'S EXPERIENCE
}

\author{
Diane L. Kelly \\ University of North Carolina at Chapel Hill, Gillings School of Global Public Health \\ Public Health Leadership Department \\ 135 Dauer Drive \\ 4111 McGavran-Greenberg Hall, CB \#7469 \\ Chapel Hill, NC 27599-7469 \\ Telephone 919-525-5142 \\ E-mail: dlkelly@email.unc.edu \\ Received on 30 June, 2013, accepted on 20 September, 2013
}

doi:10.13165/SPV-13-1-5-06

"No problem can be solved from the same level of consciousness that created it."

A. Einstein.

\section{Summary}

The focus of the article is a midsize community hospital in New York City, where the percentage of foreign-born workers, healthcare workers, doctors and nurses is higher than national levels. The hospital is located in the area containing more immigrants and higher concentrations of immigrant groups than any other part of the city. Dynamics related to the hospital's 90\% non-white, mostly foreign-born, multilingual workforce appeared to influence hospital's capability to change and improve performance. Also, observations and issues about community and organizational demographics, language context and proficiency, immigrant assimilation rates, contrasting country cultures and other related topics are explored in the article. This exploratory study revealed numerous areas that could be relevant to the quality of care, patient safety and organizational effectiveness, including language proficiency and context, cultural perceptions, immigrant assimilation and demographics of the area, in which the hospital is located.

Keywords: foreign-born healthcare workers, foreign trained healthcare workers, hospital workforce, quality improvement.

Acknowledgment. The author would like to thank Patricia Cahill for the opportunity to work with her and the hospital described in this paper. 


\section{Introduction}

Implementing and institutionalizing change initiatives and improvements occurred very slowly in the analyzed New York City hospital, compared to leaders' previous experiences with other hospitals. They needed to find ways how the improvements were hardwired with the hospital's $90 \%$ non-white, mostly foreign-born, multilingual workforce. What started as a quasi-research, quality improvement approach, evolved into this exploratory study. The root cause analysis suggested that worker demographics, immigrant assimilation, communication and country culture differences could be contributing causes of barriers to hardwiring improvement and change initiatives in the hospital. Leadership had a cursory, but not detailed knowledge of the topics and further investigation was required to identify and understand more specific causes to target the improvement. The purpose of this paper is to explore how dynamics related to a predominantly foreign-born workforce may have influenced one hospital's performance. Observations and workplace issues from a mid-size community hospital in New York City are shared in the paper.

\section{Methods}

The director of human resources provided the racial breakdown of the hospital's workforce. U.S. law prohibits employers from asking applicants about their ethnic origin, therefore, information about the hospital's performance and workforce has been derived from talking informally with hospital employees, observing day to day operations and assisting leadership in improvement efforts during a two year engagement as a regularly visiting, onsite consultant at the hospital. Descriptive statistics are based on the 2010 U.S. Census and the American Community Survey. U.S. Census reports, local government analyses and research by public policy institutes were sources of demographic and assimilation data. Other scientific studies and literature were used to learn more about the identified areas in the established root causes.

\section{Demographics}

$27 \%$ of physicians and surgeons and $15 \%$ of nurses in the United States are foreign-born, which are the circumstances not unique to America ${ }^{2}$. In New Zealand, 38.9\% of physicians and $22.1 \%$ of nurses; in Ireland, $35.5 \%$ of physicians and $47.1 \%$ of nurses; and in the United Kingdom, $31.5 \%$ of physicians and $8 \%$ of nurses were foreign-born or foreign-trained in $2008^{3}$.

2 McCabe, K. Migration Policy Institute/Foreign-Born Health Care Workers in the United States. Report. June, 2012 [interactive]. [accessed on dd-mm-yyyy]. <http://www.migrationinformation.org/USfocus/ display.cfm?id=898>.

3 Organization of Economic Co-operation and Development / International Migration of Health Workers: Improving International Co-operation to Address the Global Health Workforce Crisis. Report. February, 2010 [interactive]. [accessed on dd-mm-yyyy]. <http://www.oecd.org/els/health-systems/44783473. pdf $>$. 


\subsection{Workforce}

In 2010, 16\% of the United States' workforce was foreign-born ${ }^{4}$, while foreign born workforce comprised $42 \%$ in New York City alone. In contrast to the national data, $46 \%$ of physicians (27\% in the U.S.), more than $50 \%$ of nurses (15\% in the U.S.), and $72 \%$ of nursing, psychiatric and home health aides in New York City are currently foreign-born ${ }^{5}$. In the hospital, $90 \%$ of the entire workforce (physicians, nurses, nurses' aides, managers, medical department chiefs, ancillary departments and service workers) were non-white and predominantly foreign born ${ }^{6}$.

\section{Countries of Origin}

The most common countries of origin in the hospital, which make the focus of the paper, are India, Iran, Pakistan, Nigeria and Jamaica. The physicians tend to come from Southern Asia and Africa, nurses from the Caribbean and Africa and unlicensed service workers from the Caribbean. International medical graduates in the hospital's training program are mostly from Southern Asia.

About $4 \%$ of the total U.S. immigrant population in 2008 and the third highest origin country behind Mexico and the Philippines was India ${ }^{7}$. Immigrants from Africa made up $3.7 \%$ of the total U.S immigrant population in 2009 and out of these, $33.3 \%$ came from Nigeria, Ethiopia and Egypt, with Nigeria being the top country of origin with $14.1 \%{ }^{8}$. Immigrants from the Caribbean made up 9\% of the total U.S. immigrant population in 2009, with $90 \%$ coming from Cuba, Dominican Republic, Jamaica, Haiti, and Trinidad and Tobago?.

\subsection{Distribution and Population Density: City}

New York is one of the top four destination states and New York City is one of the top five destination metropolitan areas for the U.S. immigrants ${ }^{10},{ }^{11}$. Out of all Indian immigrants in the U.S., $17.1 \%$ lived in the New York City metropolitan area in 2008 and another $10.9 \%$ lived

$4 \quad$ McCabe, K. June, 2012, op. cit.

5 DiNapoli, T.P.; Bleiwas, K.B. The Role of Immigrants in the New York City Economy. Office of the State Comptroller, New York City Public Information Office. 2010 [interactive]. [accessed on dd-mm-yyyy]. $<$ http://www.osc.state.ny.us/osdc/rpt17-2010.pdf>, p. 1.

6 Internal hospital document.

7 Terrazas, A. and Batog, C. Migration Policy Institute/U.S. in Focus: Indian Immigrants in the United States. Report. June, 2010 [interactive]. [accessed on dd-mm-yyyy]. <http://www.migrationinformation.org/ USfocus/display.cfm?ID=785>.

8 McCabe, K. Migration Policy Institute / U.S. in Focus: African Immigrants in the United States. Report. July, 2011 [interactive]. [accessed on dd-mm-yyyy]. <http://www.migrationinformation.org/feature/ display.cfm? ID $=847>$.

9 McCabe, K. Migration Policy Institute / U.S. in Focus: Caribbean Immigrants in the United States. Report. April, 2011 [interactive]. [accessed on dd-mm-yyyy]. <http://www.migrationinformation.org/ USfocus/display.cfm?ID=834\#15>.

10 USA. Department of Commerce. Census Bureau. American Community Survey Reports. By Grieco, E.M.; De La Cruz, Y.D.; Gambino, C.; Larsen, L.J.; Trevelyan, E.N. 2012 [interactive]. [accessed on ddmm-yyyy]. <http://www.census.gov/prod/2012pubs/acs-19.pdf>, p. 3.

11 Wilson, J. H. and Singer, A. Brookings /Immigrants in 2010 Metropolitan America: A Decade of Change. Report. October 13, 2011 [interactive]. [accessed on dd-mm-yyyy]. <http://www.brookings.edu/ research/papers/2011/10/13-immigration-wilson-singer $>$. 
in New Jersey, a state bordering New York City ${ }^{12}$. In 2009, out of all African and Caribbean immigrants, $14.2 \%$ and $34 \%$ respectively lived in the New York City metropolitan area ${ }^{13}$, ${ }^{14}$. In 2008, one third of New York City's population was foreign-born ${ }^{15}$.

\subsection{Distribution and Population Density: Borough and District}

The hospital analysed in the paper is located in central Brooklyn, one of the five New York City boroughs: Brooklyn, Manhattan, Queens, Staten Island and the Bronx. The geographic relationships of the boroughs are shown in Figure I.

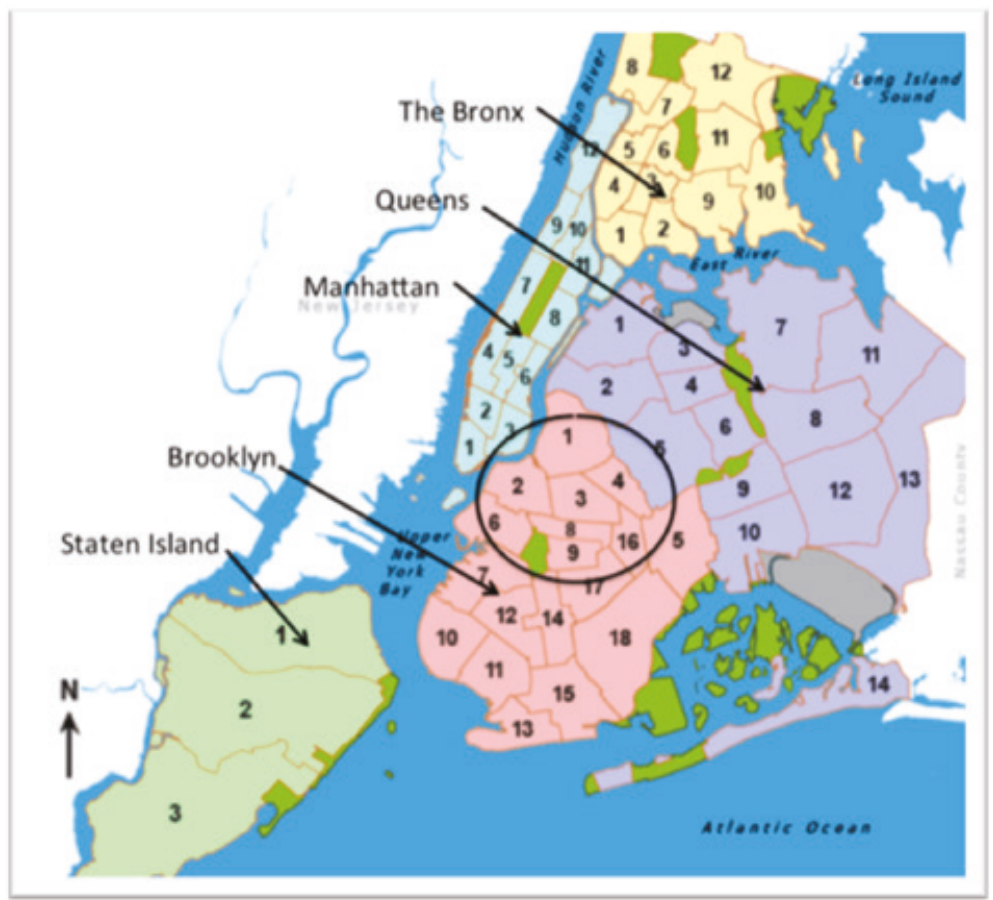

Figure I. Map of New York City Boroughs and Districts. Image entitled "NYC Community Data Portal" used with permission of the New York City Department of City Planning. All rights reserved.

Terrazas et al. June, 2010, op. cit.

McCabe, K. July, 2011, op. cit.

McCabe, K. April, 2011, op. cit.

DiNapoli, T.P. 2010, op. cit. 
In Brooklyn, 37\% of the total population is foreign-born, and in neighboring Queen's, foreign born population comprises $47 \%^{16}$. The smaller districts making up each borough are represented by the numbered areas in Figure I. The district, in which the hospital is located, along with surrounding districts of Central Brooklyn is circled. In the absence of protected personal employee data, the selected districts $(1,2,3,4,8,9$ and 16) appear to represent areas, from which many hospital workers were drawn, particularly in the department of nursing. The size of the combined districts is 17.7 square miles and the total population is over $750,000^{17}$. Table 1 shows a more detailed breakdown by race and ethnic group.

Table 1. Demographics of Central Brooklyn, 2009-2011 ${ }^{18},{ }^{19},{ }^{20}$

\begin{tabular}{|l|c|c|c|c|c|c|c|}
\hline Brooklyn District & 1 & 2 & 3 & 4 & 8 & 9 & 16 \\
\hline Area in square miles & 2.9 & 4.8 & 2.9 & 2.0 & 1.6 & 1.6 & 1.9 \\
\hline Total population (estimate) & 143,008 & 121,739 & 132,182 & 136,574 & 122,922 & 109,630 & 117,00 \\
\hline Not Hispanic or Latino*, \% & 73.4 & 82.0 & 79.8 & 33.0 & 87.6 & 92.1 & 78.5 \\
\hline White alone & 62.8 & 44.2 & 15.1 & 9.7 & 17.0 & $15.8 \%$ & 0.9 \\
\hline Black or African American alone & 3.6 & 27.2 & 59.5 & 18.4 & 65.4 & 72.6 & 76.2 \\
\hline Asian alone & 5.2 & 6.8 & 3.5 & 3.9 & 3.0 & 2.4 & .5 \\
\hline Two or more races & 1.3 & 3.1 & 1.0 & 0.5 & 1.6 & 0.8 & .6 \\
\hline Hispanic or Latino (of any race)**, \% & 26.6 & 18.0 & 20.2 & 67 & 12.8 & 7.9 & 21.5 \\
\hline Mexican & 2.4 & 2.3 & 2.2 & 12.9 & 1.1 & 0.4 & 0.9 \\
\hline Puerto Rican & 12.4 & 8.3 & 9.8 & 22.7 & 4.4 & 2.5 & 10.5 \\
\hline Other Hispanic or Latino & 11.5 & 6.9 & 7.9 & 31.0 & 7.0 & 4.9 & 9.9 \\
\hline Foreign born entered in 2000 or later, \% & 26.0 & 30.9 & 30.3 & 39.7 & 22.8 & 26.3 & 24.8 \\
\hline
\end{tabular}

${ }^{*}$ race

${ }^{* *}$ ethnicity

Even though Puerto Rico is a U.S. commonwealth, the author has included it in Table 1 due to its cultural similarities with other countries in the Caribbean region. It has to be noted that the census category Black or African American alone can include native-born African Americans, foreign-born African Americans and foreign born blacks from the Caribbean and Latin America. In addition, because the census data is completed using personal surveys, it is

16 USA. New York City. Department of City Planning. NYC Community Data Portal /DP05: Demographic and Housing Characteristics, 2009-2011 American Community Survey 3-Year Estimates, New York City Community Districts. [interactive]. [accessed on dd-mm-yyyy]. <http://www.nyc.gov/html/dcp/pdf/ census/puma_demo_09to11_acs.pdf>.

17 Ibid.

18 USA. New York City Department of City Planning. NYC Community Data Portal /DP05: Demographic and Housing Characteristics, 2009-2011 American Community Survey 3-Year Estimates, New York City Community Districts. [interactive]. [accessed on dd-mm-yyyy]. <http://www.nyc.gov/html/dcp/pdf/ census/puma_demo_09to11_acs.pdf>.

19 USA. New York City Department of City Planning. NYC Community Data Portal. [interactive]. [accessed on dd-mm-yyyy]. <http://www.nyc.gov/html/dcp/html/neigh_info/nhmap.shtml>.

20 USA. New York City Department of City Planning. NYC Community Data Portal: Selected Social Characteristics, 2008-2009 American Community Survey 3-Year Estimates, New York City Community Districts. [interactive]. [accessed on dd-mm-yyyy]. $<$ http://www.nyc.gov/html/dcp/pdf/census/puma_ socio_08to10_acs.pdf\#bk3>. 
not possible to tell if Caribbean immigrants have self-identified as Black or Latino ${ }^{21}$. Districts 3, 8,9 and 16 are made up of Black or African American, ranging from 59.5\% up to $76.2 \%$. District 9 has the highest concentration of Black or African Americans in New York City and District 4 has a $53.7 \%$ combined concentration of Puerto Rican and other Hispanic or Latino residents ${ }^{22}$.

\subsection{Immigrant Neighborhoods}

Historically, immigrants from the same country group settled together to form country communities. U.S. born and West Indian blacks tend to gravitate towards black communities concentrated in Brooklyn and southeast Queens ${ }^{23}$. Nine of the ten neighborhoods with the highest concentration of immigrants in New York City are located in Brooklyn and neighboring Queens and range from $47 \%$ to $57 \%$ of foreign-born residents ${ }^{24}$. The fourth largest immigrant neighborhood is located in central Brooklyn and consists of Caribbean immigrants from Jamaica, Haiti, and Trinidad and Tobago ${ }^{25}$.

\subsection{Summary/Implications}

New York City is a top destination metropolitan area for immigrants to the U.S., with one third of its population being foreign born and $42 \%$ of its workforce being foreign born, as well. As a percentage of the U.S. total, Africa and Jamaica immigrants are relatively low compared to the top origin countries; however, relatively high proportions of these groups gravitate to New York City. Brooklyn, the borough, in which the analysed hospital is located, and neighboring Queens contain the highest percentage of immigrants and nine of the ten most concentrated immigrant neighborhoods. Central Brooklyn, where the hospital is actually located, contains the district with the highest concentration of blacks and the neighborhood with the highest concentration of Caribbean immigrants in New York City. In addition to influencing the patient population, the surrounding geographic area may also have influenced the workforce pool in the hospital. Other countries around the world, experience even larger percentages of foreign-born healthcare workers; and while relevant, geographic concentrations of immigrants, particularly in large metropolitan areas, is beyond the scope of this paper.

\section{Assimilation}

With its rich history of immigration, the United States is often referred to as a melting pot of cultures, a phrase used to describe the unique blend of characteristics, traditions and beliefs that make up American culture. Immigrant countries of origin have been varying over the years, depending on economic, political and social conditions, and certain countries have

${ }^{21}$ USA. New York City Department of City Planning. NYC Community Data Portal: Selected Social Characteristics, 2008-2009 American Community Survey 3-Year Estimates, New York City Community Districts. [interactive]. [accessed on dd-mm-yyyy]. $<\mathrm{http} / /$ www.nyc.gov/html/dcp/pdf/census/puma_ socio_08to10_acs.pdf\#bk3>.

22 Ibid.

23 Fessenden, F. and Roberts, S. Then as Now - New York's Shifting Ethnic Mosaic. New York Times. The New York Times. 2011 [interactive]. [accessed on dd-mm-yyyy]. <http://www.nytimes.com/ interactive/2011/01/23/nyregion/20110123-nyc-ethnic-neighborhoods-map.html?_r=0>.

24 DiNapoli, T.P., op. cit., p. 2.

25 Ibid., p. 3. 
dominated the immigrant population at different times in American history. In recent years, the Caribbean, Latin America and Asia have been the top countries of origin. Assimilation or integration is the process, by which immigrants adapt to their new country, and it becomes more difficult to differentiate them from the American born population. Economic, social, political and cultural factors, all contribute to this process ${ }^{26},{ }^{27}$.

\subsection{Workforce}

Table 2 presents immigrant healthcare employment by percentage of total immigrants by the region of origin. Talking about African immigrants, more worked as nurses than physicians and the percentage of male physicians was greater than female physicians. Male and female physicians made up 10\% of immigrants from India and 16\% from Pakistan, with females outnumbering males from both countries; few Indian or Pakistani immigrants were nurses. In 2010, Caribbean immigrants were employed only as nurses. African and Caribbean immigrants working in unlicensed healthcare support positions were about five times that of Indian and Pakistani immigrants. Generally, the hospital appeared to reflect this distribution.

\subsection{Assimilation Index}

Assimilation occurs over time and involves numerous variables. The assimilation metric can be used to measure, trend and compare the degree of assimilation of different immigrant groups. Vigdor has developed the metric called the assimilation composite index, consisting of three sub-indices: economic, cultural and civic. The Economic Index consists of earned income, employment, occupational prestige, level of education and labor force participation. The Cultural Index consists of English proficiency, marital status, number of children in the household and intermarriage. The Civic Index consists of naturalization status and past or current military service ${ }^{28}$.

On a scale of 1-100, the composite assimilation index of foreign-born residents in the U.S. was calculated to be 28 in $2007^{29}$. Composite assimilation indices by birthplace were also reported. The assimilation indices of countries of origin that comprised both large and small groups in the hospital ranged from $16 \%$ to $52 \%$, with Afghanistan having $34 \%$, China - 22\%, Dominican Republic - 34\%, Ghana - 34\%, Grenada - 48\%, Haiti - 33\%, India - 16\%, Iran $50 \%$, Jamaica $-52 \%$, Nigeria - 31\%, Philippines $-49 \%$, Trinidad and Tobago $-47 \%$ and Ukraine $-28 \%{ }^{30}$.

26 Jimenez, T. R. Migration Policy Institute and the European University Institute / Immigrants in the United States: How Well Are They Integrating into Society. Report. 2011 [interactive]. [accessed on dd-mmyyyy]. <http://www.migrationpolicy.org/pubs/integration-jimenez.pdf $>$.

27 Vigdor, J. L. Manhattan Institute for Policy Research / Measuring Immigrant Assimilation in the United States. Report. October, 2009 [interactive]. [accessed on dd-mm-yyyy]. <http://www.manhattaninstitute.org/html/cr_59.htm>.

28 Vigdor, J.L. 2009, op. cit., note: includes detailed methodology.

29 Ibid.

30 Ibid. 


\subsection{Assimilation Over Time}

As time passes, one would expect the assimilation to increase also; however, Vigdor notes that the cultural index has made little progress during the first 15 years in America ${ }^{31}$. Without specific date of arrival in the U.S. from hospital employees, the 2010 census data element, immigrants arriving since 2000, may serve as a general proxy of the numbers of years in the U.S. Overall, $47.7 \%, 34.4 \%$ and $25.4 \%$ of immigrants from Africa, India and the Caribbean respectively have arrived since $2000^{32},{ }^{33},{ }^{34}$. Talking about Brooklyn districts, foreign-born residents entering the U.S. in 2000 or later ranged from $22.8 \%$ to $39.8 \%$ (see Table 1$)^{35}$.

\subsection{Summary/Implications}

New York City substantially exceeds the national percentage of foreign-born healthcare physicians and nurses. In addition, almost three fourths of all nursing, psychiatric and home health aides in New York City are foreign born. These three groups combined made up the largest proportion of direct patient care providers in the hospital. Assimilation of immigrants can be measured: the composite immigrant assimilation index provides a general picture of assimilation for country groups of interest at the hospital. Almost half of Africans, one third of Indians and one quarter of Caribbean immigrants have lived in the U.S. within the timeframe, during which cultural assimilation made little progress. Due to the nature of the professions, foreign-born doctors and nurses most likely scored favorably on the economic assimilation index, which may mask lower scores on the other two indices. The lower educational requirements, position prestige, salaries of nursing, psychiatric and home health aides suggest that their assimilation index is lower than for the licensed professionals.

\section{Language}

With few exceptions, English is the language of U.S hospitals. English as a second language for the hospital's multinational workforce adds layers of complexity to an already complex hospital environment. Through spoken communication in multinational groups, problems can arise in comprehending messages, working with a limited vocabulary, understanding accents and processing fast paced conversations ${ }^{36}$.

\footnotetext{
Ibid.

McCabe, K. April, 2011, op. cit.

Terrazas, A. and Batog, C. 2010, op. cit.

McCabe, K. July, 2011, op. cit.

3 USA. New York City. New York City Department of City Planning. NYC Community Data Portal: Selected Social Characteristics, 2008-2009 American Community Survey 3-Year Estimates, New York City Community Districts. [interactive]. [accessed on dd-mm-yyyy]. <http://www.nyc.gov/html/dcp/ pdf/census/puma_socio_08to10_acs.pdf\#bk3>.

36 Rogerson-Revell, P. "Can You Spell That for Us Nonnative Speakers?": Accommodation Strategies in International Business Meetings. Journal of Business Communication 47. 2010, 4: 432-454.
} 


\subsection{Language and Culture}

Culture is defined as "an often subconscious; an invisible control mechanism operating in our thoughts" ${ }^{37}$. Intercultural communication is defined as "the intricate relationship between language, thought, and culture" ${ }^{38}$. Communication within the hospital, with its relatively small group of workers, to whom English is a first language, occurred frequently between non-native English speakers. Hospital communications involved American English and variations of English as a second language (ESL) that reflected different cultural influences, perceptions, vocabulary and expectations. Consequently, communication combinations included EFL to EFL, EFL to ESL, ESL to EFL, and ESL to ESL.

One way to differentiate languages is by context, defined as "the unquestioning assumptions through which all experience is filtered" ${ }^{39}$. High context languages "depend on internal meaning, background knowledge and nonverbal communication, a combination resulting in indirect, ambiguous, harmonious, reserved, and understated verbal communication" ${ }^{\text {"40 }}$. In contrast, communication in low context cultures depends on the explicit statement of meaning, resulting in communication that is "direct, precise, dramatic, open and based on feelings or true intentions" ${ }^{\text {"11 }}$. Both high and low context languages were used by the hospital's workforce.

\subsection{Language and Assimilation}

Rapid immigration combined with concentrated country neighborhoods create conditions, in which language proficiency of the overall group tends to worsen ${ }^{42}$. The hospital's geographic location met both of these conditions. In New York City, immigrant workers increased by $68 \%$ between the years 2000-2008 and, as stated earlier, Brooklyn and Queens contain nine of the ten most concentrated neighborhoods in New York City ${ }^{43},{ }^{44}$.

When faced with delayed English proficiency and heavily accented spoken English, both speakers and listeners accommodate in order to function in the day-to-day workplace. Speakers repeat, rephrase and slow down to get their message across; however, listeners, often adopt the "Let It Pass" approach, in which they tolerate the disparities in the language and attempt to understand the general message, missing the details and unspoken messages ${ }^{45}$. Spoken English proficiency not only influences the degree, to which parties understand each other, but it also influences the way how they perceive each other, e.g., lack of spoken English proficiency may

37 Nishimura, S., Nevgi, A. and Tella, S. Communication Style and Cultural Features in High/Low Context Communication Cultures: A Case Study of Finland, Japan and India. Proceedings of a Subject-Didactic Symposium, Finland, Helsinki. February 2, 2008 [interactive]. [accessed on dd-mm-yyyy]. <http:// www.helsinki.fi/ tella/nishimuranevgitella299.pdf>, p. 784.

38 Sharifian, F. and Jamarani, M. Language and Intercultural Communication in the New Era. New York: Routledge, 2013; Farzad, S. and Jamarani, J. (eds.). Language and Intercultural Communication in the New Era. New York: Routledge, 2013, p. 1.

39 Davis, S. Transforming Organizations: The Key to Strategy Is Context. Organizational Dynamics 10. 1982, 3: 64-80.

$40 \quad$ Nishimura, S. et al. 2008, op. cit., p. 784.

${ }^{41} \quad$ Ibid., p. 785.

42 Vigdor, J.L. 2009, op. cit.

43 DiNapoli, T.P. 2010, op. cit.

$44 \quad$ Ibid.

45 Rogerson-Revell, P. Participation and Performance in International Business Meetings. English for Specific Purposes 27. 2008, 3: 338-60. 
lead one to believe "that the other is either intellectually incompetent or deliberately uncooperative or combative" ${ }^{" 46}$.

\subsection{Language and Cognition}

The type of information gathered and how that information is processed depend on cultural backgrounds $s^{47}$. To be a successful healthcare provider, knowledge and critical thinking are required, both of which are tested to obtain a professional license in the U.S. Foreign-educated professionals must demonstrate English competency, have their program reviewed to ensure academic equivalency and pass their respective licensing exams ${ }^{48},{ }^{49}$. In New York, if the official language of one's home country is English, as in the countries described above, applicants may be exempted from proof of language proficiency ${ }^{50}$. Before foreign trained medical students and graduates can apply to take the United States Medical Licensing Examination (USMLE), they must first pass a certification exam. Foreign trained nurses may also take the certification exam and must pass the NCLEX (National Council Licensing) that "measures the competencies needed to perform safely and effectively as a newly licensed, entry-level nurse" to receive a professional license $\mathrm{e}^{51}$.

Interestingly, even though the educational programs have already been granted equivalency, for the first time certification and exam pass rates for foreign trained professionals are consistently and notably lower than American trained professionals. Out of 267,000 foreign trained medical students and graduates taking the USMLE exam between 1986 and 2005, 57.2\% received certification ${ }^{52}$. In 2010, 87.4\% of the first time U.S. educated nurse candidates passed the NCLEX exam, while only $38.6 \%$ of the internationally educated nurse candidates passed the NCLEX exam ${ }^{53}$.

\subsection{Summary/Implications}

Language has implications far beyond words spoken and heard. Language proficiency influences immigrant assimilation; context influences perceptions and, in turn, how spoken language is delivered, what is delivered, how messages are received, and what the impressions about the speaker are. All of these factors converge in a multinational hospital, where workers predominantly speak English as a second language. Because effective communication is es-

46 Rogerson-Revell, P. 2010, op. cit.

47 USA. U.S. Army War College. Office of the Director of National Intelligence and the Center for Strategic Leadership. Truth, Perceptions and Consequences. By MacNulty, C.A. Vol. 1. Proteus Management Group, 2007.

48 Education Commission on Foreign Graduates. About ECGF. [interactive]. [accessed on dd-mm-yyyy]. $<$ http://www.ecfmg.org/about/index.html $>$.

49 Commission on Graduates of Foreign Nursing Schools. Credential Evaluation Service. [interactive]. [accessed on dd-mm-yyyy]. <http://www.cgfns.org >.

50 USA. New York State Education Department. Office of the Professions. Regulations of the Commissioner of Education, Part 59: General Provisions, \$ 59.3 E. 2012.

51 National Council of State Boards of Nursing. About NCLEX. [interactive]. [accessed on dd-mm-yyyy]. $<$ https://www.ncsbn.org/nclex.htm>.

52 Education Commission on Foreign Medical Graduates. About ECGF Certification. [interactive]. [accessed on 04-10-2013]. <http://www.ecfmg.org/certification/index.html>.

53 Woo, A.; Gross, L.; Weiwei, L. 2010 Nurse Licensee Volume and NCLEX Examination Statistics. National Council of State Boards of Nursing, Inc. National Council of State Boards of Nursing, Inc. 2011. 
sential to safe, quality healthcare, attention to the above language related issues is warranted, especially in situations with large groups of multinational workers, such as hospital. Finally, the role of context and perceptions in foreign-born professional licensure and certification exams might be considered in light of pass rates compared to the American counterparts.

\section{Cultural Characteristics}

As mentioned earlier, three different regions of the world, each with their unique cultures, made up the hospital workforce. Physicians tended to come from Southern Asia and Africa, nurses from the Caribbean and Africa, service workers from the Caribbean and physicians in training from Southern Asia.

\subsection{Measuring Culture}

The following dimensions influenced by culture were measured in the GLOBE study: performance orientation, future orientation, gender egalitarianism, assertiveness, individualization and collectivism, power distance, humane orientation, and uncertainty avoidance ${ }^{54}$. Four of the countries of interest in the hospital participated in the GLOBE study: the U.S., Iran, India and Nigeria. A variety of Central American, South American and European Latino countries were included in the study; however, no country from the Caribbean participated. The hospital's four countries of interest tended to cluster together in various combinations for most dimensions; however, in two dimensions, three countries were grouped together and the U.S. was distinctly separate. The three countries were ranked higher than the U.S. in activities associated with power distance ("the extent to which a community accepts and endorses authority, power differences, and status privileges") and notably higher than the U.S. in activities associated with in-group collectivism (emphasis on relatedness with groups and individuals; greater distinctions between in-groups and out-groups; slower pace of life $)^{55},{ }^{56}$.

\subsection{Summary/Implications}

Iran, India and Nigeria were ranked higher than the U.S. in the power distance dimension and notably higher than the U.S. in the in-group collectivism dimension in the GLOBE study. Even though the study results are not generalizable to individuals, differences at the individual and work group levels could be problematic in a multinational workforce and unfavorable for establishing effective teamwork, accountability or quality improvement in managerial or clinical hospital settings.

54 House, R.J.; Hanges, P.J.; Javidan, M.; Dorfman, P.W.; Gupta, V. (eds.). Culture, Leadership, and Organizations in the GLOBE Study of 62 Societies. Thousand Oaks, CA: Sage, 2004.

55 Carl, D.; Gupta, V.; Javidan, M. Power Distance. In: House, R.J.; Hanges, P.J.;Javidan, M.; Dorfman, P.W.; Gupta, V. (eds). Leadership, and Organizations in the GLOBE Study of 62 Societies. Thousand Oaks, CA: Sage, 2004, p. 513.

56 Gelfand, M.; Bhawuk, D.P.S.; Nishii, L.H.; Bechtold, D.J. Individualism and Collectivism. In: House, R.J.; Hanges, P.J.; Javidan, M.; Dorfman, P.W.;Gupta, V. (eds.). Culture, Leadership, and Organizations in the GLOBE Study of 62 Societies. Thousand Oaks, CA: Sage, 2004, p. 454. 


\section{Hospital: Observations and Consequences}

Demographics, assimilation, language and culture appeared to converge and interact in the analysed hospital with its predominantly multinational and multilingual workforce and may have contributed to difficulties in hardwiring improvements required by the contemporary U.S. healthcare environment.

\subsection{Demographics and Assimilation}

New York City, the boroughs of Brooklyn and Queens, and central Brooklyn demographics appear to have nurtured the workforce in the hospital that was predominantly foreign born with variable rates of assimilation. Country group allegiance could be seen when physicians frequently delivered friends and relatives resumes to the nursing department expecting them to be hired based on ties to their country community rather than based on the applicant's qualifications and competences.

\subsection{Language}

Imagine the implications of a patient cardiac arrest, where a physician with a heavy Indian accent is directing the "code" team made up of a nurse with a heavy African accent, a nurse with a heavy Caribbean accent, a nursing supervisor with a heavy Eastern European accent and a pharmacist with a heavy Chinese accent. This was not an uncommon combination of clinical team members at the hospital, each with their respective language, perceptions and culturally influenced cognitive processes. At the combined clinical and department head meetings, talk after the meetings indicated that participants could not understand what certain foreign born department heads had said or reported. The "Let It Pass" approach appeared to have been adopted, as asking for clarification was the exception rather than the norm. Many foreign-born physician and nurse leaders exemplified the "indirect, ambiguous, harmonious, reserved and understated" communication of high context cultures, which appeared to American executives that their conflict resolution skills and ability to promote accountability were weak. On the other hand, the American's assertive and direct communication style was probably perceived by foreign-born workers as disrespectful.

Lower language proficiency appeared to accompany low computer proficiency, required for using the electronic medical record, and also played a part in operational efficiency. At times, language context detracted from white leaders' ability to build relationships with others in the organization. What they considered to be ice-breaking humor was often met with silence. Even interactive learning and team building activities, facilitated by the author and effective with other international audiences, did not have the anticipated positive impact. At times, it appeared that concepts targeted from the learning activities did not fit with how workers processed information or was not present in their own world-view.

Language related communication breakdowns can hinder efforts to improve and maintain the managerial, financial and operational infrastructure required to support safe, quality patient care. Communication breakdowns can contribute to latent management errors, where the consequences may not be seen until an unpredictable future point in time ${ }^{57}$. Communication

57 Hofman, P. B. and Perry, F. Management Mistakes in Healthcare: Identification, Correction and Protection. Cambridge: Cambridge University Press, 2005. 
breakdowns at the patient-provider and provider-provider interfaces can lead to active errors at the bedside and, in turn, affect the quality of care received by patients ${ }^{58}$.

\subsection{Country Culture: In-group Collectivism}

Too much group cohesion can lead to exclusion and groupthink. Licensed and unlicensed worker groups tended to revert to first languages in large public spaces (hallways, cafeteria) and in smaller places (offices). Even in patient care areas, physicians and physicians in training would speak their first language when discussing clinical issues with each other. Speaking in one's native tongue reflects one's degree of assimilation; however, practice may have also reinforced the exclusion associated with high in-group collectivism. Because physicians and nurses tended to have different countries of origin in the hospital, the practice may also have accentuated the historic separateness of professional healthcare hierarchies.

To bring disparate groups in the organization together, senior leaders revisited the mission/ vision, sponsored management developments workshops and presented hospital with wide quality, financial, human resources and customer service metrics at monthly manager meetings. The nursing department put into place a collaborative leadership team to reduce the silo mentality between acute care, ambulatory care, and the emergency department, used monthly leadership meetings and visioning workshops to promote common nursing values within the department, hired a Director of Professional Practice to unify and promote a common standard of care and implemented and reviewed monthly unit based and departmental quality metrics. Despite these leadership interventions, little progress was made towards the desired hospital and professional group identities.

Nurses, physicians in training and unlicensed workers, all participated in their own unions. Managers, but not executives, were entitled to union membership. With their own union, a large portion of foreign-born unlicensed nursing aides at the hospital developed a solidarity that was reportedly much stronger in the analysed hospital than in other healthcare organization throughout the city. Even though the nursing aides did not have the positional authority, they wielded their own influence and power. From their union, "activists and diehards... strongly motivated to oust their leaders by any means necessary" emerged, seemingly because the leaders were white ${ }^{59}$. The most common methods used to block legitimate disciplinary action and prevent quality initiatives were ignoring a superior's decision, circumventing one's superior via in-group member influence and threatening discrimination. These actions often proved to be more powerful than those of the "out-group" executive leaders. These informal leaders fostered the "we/they" atmosphere that restricted the American born executives' ability to shape and disseminate American healthcare values, strategy and operational efficiencies.

\subsection{Country Cultures: Power Distance}

Safe, quality patient care requires teamwork and collaboration, organizational characteristics that typically require low power distance characteristics. Organizational models aimed at breaking down departmental silos that separate team members have been used in U.S. hospitals. Patient safety tools, such as the SBAR (situation, background, assessment, recommendations),

58 Reason, J. T. Managing the Risks of Organizational Accidents. Aldershot, Hants, England: Ashgate, 1997.

59 Kellerman, B. What Every Leader Needs to Know about Followers. Harvard Business Review 85. 2007, 12: 84-91. 
are designed to promote clear and direct communication. Healthcare quality and safety efforts have focused on lowering power distances for the past 25 years in the U.S. Shared governance, which emphasizes empowerment, has been the participative management model of choice for nurses. Continuous quality improvement has emphasized using interdisciplinary teams and engaging the people who do the work to help improve the work. Safety culture requires team members to alert the team if an unsafe act is about to be committed. Reducing hierarchies serves as the premise behind the World Health Organization endorsed surgical "time out"60. Despite role modeling and coaching, interdisciplinary patient rounds persisted with the physicians telling the medical plan to the rest of the team members.

In cultures with high power distance, "workforces have been accustomed to depend on their supervisors for direction" ${ }^{\prime 61}$. In the hospital, workers needed ongoing oversight to ensure compliance with policies and procedures. Instead of embracing opportunities of empowerment, they appeared to reject them. Even managers needed considerable instruction and ongoing oversight from senior leaders to ensure their job duties were being carried out and required much cajoling to meet deadlines, such as annual performance appraisals and required management reports.

The slower pace of life, associated with high-power distance countries, interfered with productivity and project completion. Work days started with social conversations and extended breakfasts in the cafeteria before "official" work began. Employees were often late to or absent from meetings and could be found socializing instead; while acceptable in other cultures, American leaders tended to view this behavior as disrespectful. Efforts to improve waiting times and patient throughput in the Emergency Department or on-time procedure starts in the operating room were met with strong resistance over and over again. The hospital lagged behind the nation in implementing evidence-based practices to meet regulatory and government quality requirements.

With a foreign-born population, power distance in the country of origin could also influence how workers perceive their healthcare colleagues e.g., in Iran, medical doctors are included in the elite of society ${ }^{62}$. In India, except for merit quotas, medical schools are for the wealthy ${ }^{63}$. One hospital physician explained the deferential relationships between the physicians/physicians in training and other healthcare workers, as "they (physicians) are used to having servants at home" and tended to treat nurses and other workers accordingly. The expectation to drop everything to meet the physicians' need made nurses' time management in the clinical areas extremely difficult. African healthcare professionals in the hospital often depended on their traditional African positional power as the preferred approach to getting work done rather than developing their own personal leadership skills.

60 World Health Organization / Implementation Manual Surgical Safety Checklist. 1st edition. Report. [interactive]. [accessed on dd-mm-yyyy]. <http://www.who.int/patientsafety/safesurgery/tools_ resources/SSSL_Manual_finalJun08.pdf>.

61 Carl, D. et al. 2004, op. cit.

62 Parvizian, J.; Khademolqorani, S.; Tabatabaei, M.H.A. System Dynamics Modeling of Emigration and Brain Drain: The Case of Iran. Proceedings of Conference [of] the System Dynamics Society, Albuquerque, New Mexico, USA. 2009 [interactive]. [accessed on dd-mm-yyyy]. <http://www. systemdynamics.org/conferences/2009/proceed/index.html>.

63 Ball, A. M. Medicine, Merit, Money and Caste: The Complexity of Medical Education in India. Indian Journal of Medical Ethics 7. 2010, 1: 25-28. 


\section{Conclusions and Further Research}

1. Reportedly, the hospital workforce had previously contained a healthy balance of diversity. At some point in time, it appeared to have reached a tipping point that transformed the diversity from an asset to a liability. The boiling frog story seems to apply here. As the story goes, if one puts a frog into boiling water, it will jump out. If one puts a frog into cold water and heats the water until it boils, the frog will boil to death before it realizes the water is boiling.

2. The author acknowledges that the observations occurred informally and through an American health care lens and that in addition to the causes identified here, other organizational factors likely influenced hospital performance. Exploring the originally identified root causes has revealed a combination of causes that appear to be embedded, structural issues within the system. While the cause and effect diagram is drawn in a linear fashion (see Figure II), the causes identified in this exploratory study appear to be interrelated.

3. Collaborating with cultural linguists and intercultural communications experts could offer insights about how language may influence the individual, work group and organizational performance in the healthcare delivery setting. Additional studies to better understanding and manage assimilation into the American health care culture can continue to guide organizational leaders ${ }^{64},{ }^{65}$. Immigration has helped to meet a demand for healthcare workers in some countries; however, other organizational issues may arise as the proportion of foreign born workers in a single organization grows.

\section{References}

1. Education Commission on Foreign Medical Graduates. About ECGF Certification. [interactive]. [accessed on 04-10-2013]. <http://www.ecfmg.org/certification/index.html>.

2. Education Commission on Foreign Graduates. About ECGF. [interactive]. [accessed on ddmm-yyyy]. <http://www.ecfmg.org/about/index.html>.

3. National Council of State Boards of Nursing. About NCLEX. [interactive]. [accessed on ddmm-yyyy]. <https://www.ncsbn.org/nclex.htm>.

4. Ball, A. M. Medicine, Merit, Money and Caste: The Complexity of Medical Education in India. Indian Journal of Medical Ethics 7. 2010, 1:25-28.

5. Britz, E. and Batalova, J. Migration Information Source - Frequently Requested Statistics on Immigrants and Immigration in the United States. The Migration Information Source. 2013 [interactive]. [accessed on 04-10-2013]. <http://www.migrationinformation.org/ USFocus/display.cfm?ID=931>.

6. Carl, D.; Gupta, V.; Javidan, M. Power Distance. In: House, R. J.; Hanges, P. J.; Javidan, M.; Dorfman, P. W.; Gupta, V. (eds.). Leadership, and Organizations in the GLOBE Study of 62 Societies. Thousand Oaks, CA: Sage, 2004, p. 513-563.

${ }^{64} \mathrm{Lu}, \mathrm{H}$. and Maithus, C. Experiences of Clinical Tutors with English as an Additional Language (EAL) Student. Nursing Praxis in New Zealand 28. 2012, 3: 4-12.

65 Chen, P. G.-C.; Curry, L.A.; Bernheim, S.M.; Berg, D.; Gozu, A.; Nunez-Smith, M. Professional Challenges of Non-U.S.-Born International Medical Graduates and Recommendations for Support During Residency Training. Academic Medicine. 2011, 86: 1383-1388. 
7. Chen, P. G.-C.; Curry, L. A.; Bernheim, S. M.; Berg, D.; Gozu, A.; Nunez-Smith, M. Professional Challenges of Non-U.S.-Born International Medical Graduates and Recommendations for Support During Residency Training. Academic Medicine. 2011, 86: 1383-1388.

8. Commission on Graduates of Foreign Nursing Schools. Credential Evaluation Service. [interactive]. [accessed on dd-mm-yyyy]. <http://www.cgfns.org $>$.

9. Davis, S. Transforming Organizations: The Key to Strategy Is Context. Organizational Dynamics 10. 1982, 3: 64-80.

10. DiNapoli, T. P. and Bleiwas, K. B. The Role of Immigrants in the New York City Economy. Office of the State Comptroller. 2010 [interactive]. [accessed on dd-mm-yyyy]. <http:// www.osc.state.ny.us/osdc/rpt17-2010.pdf>.

11. Fessenden, F. and Roberts, S. Then as Now - New York's Shifting Ethnic Mosaic. New York Times. The New York Times. 2011 [interactive]. [accessed onm dd-mm-yyyy]. <http://www. nytimes.com/interactive/2011/01/23/nyregion/20110123-nyc-ethnic-neighborhoods-map. html?_r=0>.

12. Gelfand, M.; Bhawuk, D. P.S.; Nishii, L. H.; Bechtold, D J. Individualism and Collectivism. In: House, R. J.; Hanges, P. J.; Javidan, M.; Dorfman, P. W.; Gupta, V. (eds.). Culture, Leadership, and Organizations in the GLOBE Study of 62 Societies. Thousand Oaks, CA: Sage, 2004 , p. 437-512.

13. Hakimazdeh, S. and Dixon, D. Migration Policy Institute / Spotlight on the Iranian Foreign Born. Report. June, 2006 [interactive]. [accessed on dd-mm-yyyy]. <http://www. migrationinformation.org/USFocus/display.cfm? ID $=404>$.

14. Hofman, P. B. and Perry, F. Management Mistakes in Healthcare: Identification, Correction and Protection. Cambridge: Cambridge University Press, 2005.

15. House, R. J.; Hanges, P. J.; Javidan, M.; Dorfman, P. W.; Gupta, V. (eds.). Culture, Leadership, and Organizations in the GLOBE Study of 62 Societies. Thousand Oaks, CA: Sage, 2004.

16. Jimenez, T. R. Migration Policy Institute and the European University Institute / Immigrants in the United States: How Well Are They Integrating into Society. Report. [interactive]. [accessed on dd-mm-yyyy]. <http://www.migrationpolicy.org/pubs/integration-jimenez. pdf $>$.

17. Kellerman, B. What Every Leader Needs to Know about Followers. Harvard Business Review 85. 2007, 12: 84-91.

18. Lu, H. and Maithus, C. Experiences of Clinical Tutors with English as an Additional Language (EAL) Student. Nursing Praxis in New Zealand 28. 2012, 3: 4-12.

19. McCabe, K. Migration Policy Institute / U.S. in Focus: African Immigrants in the United States. Report. July, 2011 [interactive]. [accessed on dd-mm-yyyy]. <http://www. migrationinformation.org/feature/display.cfm? $\mathrm{ID}=847>$.

20. McCabe, K. Migration Policy Institute / U.S. in Focus: Caribbean Immigrants in the United States. Report. April, 2011 [interactive]. [accessed on dd-mm-yyyy]. <http://www. migrationinformation.org/USfocus/display.cfm? ID $=834 \# 15>$.

21. McCabe, K. Migration Policy Institute / Foreign-Born Health Care Workers in the United States. Report. June, 2012 [interactive]. [accessed on dd-mm-yyyy]. <http://www. migrationinformation.org/USfocus/display.cfm?id=898>.

22. Nishimura, S.; Nevgi, A.; Tella, S. Communication Style and Cultural Features in High/Low Context Communication Cultures: A Case Study of Finland, Japan and India. Proceedings of a Subject-Didactic Symposium, Finland, Helsinki. February 2, 2008 [interactive]. [accessed on dd-mm-yyyy]. <http://www.helsinki.fi/ tella/nishimuranevgitella299.pdf>. 
23. Organization of Economic Co-operation and Development / International Migration of Health Workers: Improving International Co-operation to Address the Global Health Workforce Crisis. Report. February, 2010 [interactive]. [accessed on dd-mm-yyyy]. <http:// www.oecd.org/els/health-systems/44783473.pdf>.

24. Parvizian, J.; Khademolqorani, S.; Tabatabaei, M. H.A.. System Dynamics Modeling of Emigration and Brain Drain: The Case of Iran. Proceedings of the 27th International Conference of the System Dynamics Society. July 26-30, 2009. Albuquerque, New Mexico, USA.

25. Reason, J. T. Managing the Risks of Organizational Accidents. Aldershot, Hants, England: Ashgate, 1997.

26. Rogerson-Revell, P. “Can You Spell That for Us Nonnative Speakers?”: Accommodation Strategies in International Business Meetings. Journal of Business Communication 47. 2010, 4: 432-54.

27. Rogerson-Revell, P. Participation and Performance in International Business Meetings. English for Specific Purposes 27. 2008, 3: 338-360.

28. Sharifian, F.; Farzad, S.; Jamarani, M. Language and Intercultural Communication in the New Era. New York: Routledge, 2013.

29. Terrazas, A. and Batog, C. Migration Policy Institute / U.S. in Focus: Indian Immigrants in the United States. Report. June, 2010 [interactive]. [accessed on dd-mm-yyyy]. <http:// www.migrationinformation.org/USfocus/display.cfm?ID=785>.

30. USA. Department of Commerce. Census Bureau. American Community Survey Reports / The Foreign-born Population in the United States: 2010. By Grieco, E.M.; De La Cruz, Y.D.; Gambino, C.; Larsen, L.J.; Trevelyan, E.N. 2012 [interactive]. [accessed on dd-mm-yyyy]. $<$ http://www.census.gov/prod/2012pubs/acs-19.pdf $>$.

31. USA. New York City Department of City Planning. NYC Community Data Portal / DP05: Demographic and Housing Characteristics, 2009-2011 American Community Survey 3-Year Estimates, New York City Community Districts. [interactive]. [accessed on dd-mm-yyyy]. $<$ http://www.nyc.gov/html/dcp/pdf/census/puma_demo_09to11_acs.pdf >.

32. USA. New York City Department of City Planning. NYC Community Data Portal. [interactive]. [accessed on dd-mm-yyyy]. <http://www.nyc.gov/html/dcp/html/neigh_ info/nhmap.shtml>.

33. USA. New York City Department of City Planning. NYC Community Data Portal: Selected Social Characteristics, 2008-2009 American Community Survey 3-Year Estimates, New York City Community Districts. [interactive]. [accessed on dd-mm-yyyy]. <http://www.nyc.gov/ $\mathrm{html} / \mathrm{dcp} / \mathrm{pdf} /$ census/puma_socio_08to10_acs.pdf\#bk3>.

34. USA. New York Office of the State Comptroller. New York City Public Information Office. The Role of Immigrants in the New York City Economy. By DiNapoli, T. P. and Bleiwas, K.B. 2010 [interactive]. [accessed on dd-mm-yyyy]. <http://www.osc.state.ny.us/osdc/rpt172010.pdf $>$.

35. USA. New York State Education Department. Office of the Professions. Regulations of the Commissioner of Education, Part 59: General Provisions, \$59.3 E. 2012.

36. USA. U.S. Army War College. Office of the Director of National Intelligence and the Center for Strategic Leadership. Truth, Perceptions and Consequences. By MacNulty, C.A. Vol. 1. Proteus Management Group, 2007.

37. Vigdor, J. L. Manhattan Institute for Policy Research / Measuring Immigrant Assimilation in the United States. Report. October, 2009 [interactive]. [accessed on dd-mm-yyyy]. <http:// www.manhattan-institute.org/html/cr_59.htm>. 
38. Wilson, J. H. and Singer, A. Brookings / Immigrants in 2010 Metropolitan America: A Decade of Change. Report. October 13, 2011 [interactive]. [accessed on dd-mm-yyyy]. <http://www. brookings.edu/research/papers/2011/10/13-immigration-wilson-singer $>$.

39. Woo, A.; Gross, L.; Weiwei, L. 2010 Nurse Licensee Volume and NCLEX Examination Statistics. National Council of State Boards of Nursing, Inc. National Council of State Boards of Nursing, Inc. 2011 [interactive]. [accessed on dd-mm-yyyy]. <https://www.ncsbn. org/12_REVISED_2010NCLEXExamStats_Vol52.pdf $>$.

40. World Health Organization / Implementation Manual Surgical Safety Checklist. 1st edition. Report. [interactive]. [accessed on dd-mm-yyyy]. <http://www.who.int/patientsafety/ safesurgery/tools_resources/SSSL_Manual_finalJun08.pdf $>$.

Table 2. \% of Total Region / Country Immigrants Employed in American Healthcare ${ }^{66,67,68,69}$

\begin{tabular}{|l|c|c|c|c|}
\hline & $\begin{array}{c}\text { Caribbean } \\
\text { Overall } \\
\text { 2009 data }\end{array}$ & $\begin{array}{c}\text { Africa } \\
\text { Overall } \\
2007 \text { data }\end{array}$ & $\begin{array}{c}\text { India } \\
\text { 2008 data }\end{array}$ & $\begin{array}{c}\text { Pakistan } \\
\text { 2006 data }\end{array}$ \\
\hline Physicians - male & 0 & 2.3 & 4.3 & 7.6 \\
\hline Physicians - female & 0 & 1.7 & 5.7 & 8.6 \\
\hline Nurses - male & 0 & 1.0 & 0.2 & 0.4 \\
\hline Nurses - female & 4.3 & 7.3 & 5.5 & 2.3 \\
\hline Licensed $\uparrow$ Unlicensed $\downarrow$ & \multicolumn{5}{|l|}{} \\
\hline Nursing, psychiatric or home health aides* - male & 0 & 3.8 & 0.4 & 0.5 \\
\hline Nursing, psychiatric or home health aides - female & 16.2 & 12.7 & 2.4 & 2.2 \\
\hline
\end{tabular}

Figure II. Root Cause Diagram

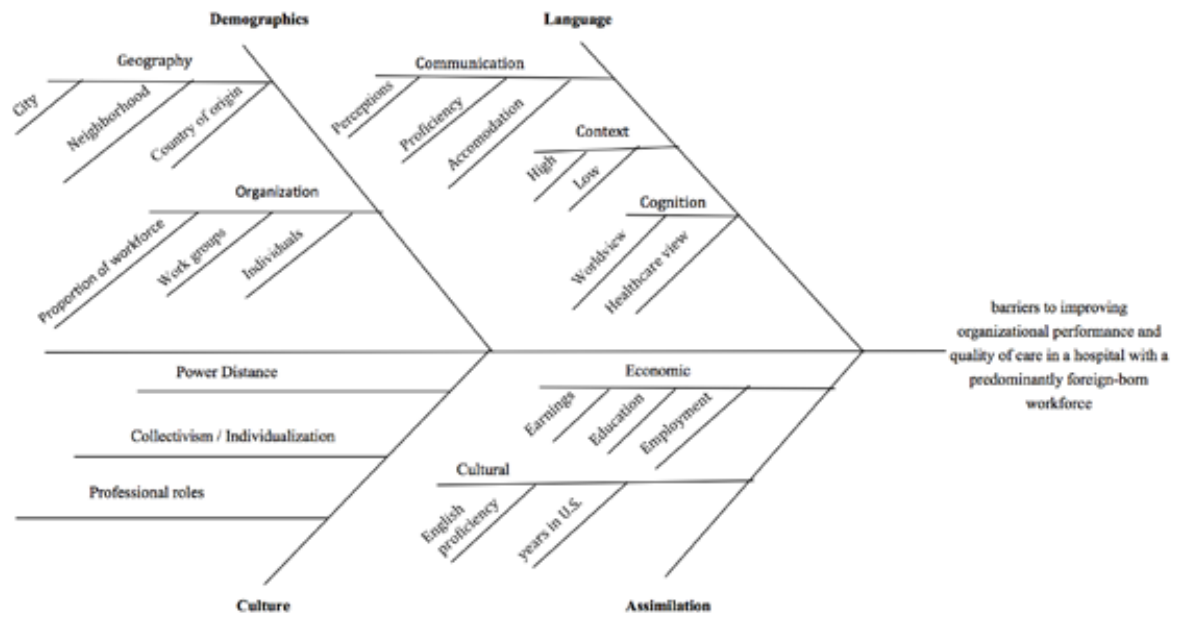

${ }_{66}$ McCabe, K. April, 2011, op. cit.

67 McCabe, K. July, 2011, op. cit.

68 McCabe, K. June, 2012, op. cit.

69 Terrazas, A. and Batog, C. June, 2010, op. cit. 


\title{
Vyraujanti užsienio kilmės ar užsienio valstybẻse apmokyta darbo jẻga: vienos ligoninès patirtis
}

\author{
Diane L. Kelly \\ Šiaurès Karolinos universitetas, Gillingo visuomenès sveikatos mokykla, \\ Jungtinès Amerikos valstijos
}

\section{Santrauka}

Šia tiriamaja studija siekiama geriau suprasti, kokia įtaka vidutinio dydžio bendruomenes ligoninei Niujorke turejo faktas, kad joje daugiausiai dirbo užsienio valstybèse gimę asmenys. Užsienyje gimusių ligoniniu aptarnaujančiujų darbuotoju ir užsienyje gimusiu gydytoju ir slaugytoju procentas Niujorke yra pastebimai didesnis lyginant su nacionaliniu lygmeniu.

Analizuojama ligoninè yra isikūrusi miesto rajone, kuris išsiskiria didesniu imigrantu skaičiumi ir didesne imigrantu grupių koncentracija lyginant su kitomis miesto dalimis. Tokia rajono aplinka lemé, kad 90 \% ligoninès personalo yra ne baltaodžiai, be to, didžioji dalis ligoninès darbuotoju yra gimę už JAV ribų. Ligoninejje sunkiai ir lètai sekési igyvendinti ir ịtvirtinti ¡̇vairias teigiamu pokyčiu iniciatyvas. Tai, kas prasidejo kaip kvazimoksliniai tyrimai kokybès gerinimo požiūriu, išsivystè $i$ šia tiriamąa studiją dèl demografijos, imigrantu asimiliacijos, komunikaciniu ir kultūrinių skirtumų reikšmès stabdant inovacijų ir pokyčių iniciatyvas. Nors užsienyje gimę sveikatos priežiūros specialistai turi galimybe gauti licencija ir legaliai dirbti JAV, per pirmuosius (pastaruosius) penkiolika metų kultūrinès asimiliacijos srityje padaryta nedidelè pažanga. Staigūs imigracijos ir imigranty koncentracijos procesai lemia kalbos mokejjimo lygio mažèjimą, kas, savo ruožtu, turi įtakos tiek komunikacijos procesams (bendravimui), tiek ir žmonių ispūdžiams. Kalba turi ịtakos komunikacijai, darbuotojo suvokimui ir jžvalgai. Šalies kontekstas įtakoja, ka ir kaip šnekamoji kalba perduodama ir kaip perduodama žinia yra suprantama. Efektyvi komunikacija yra raktas į pacientu sauguma. Atsižvelgiant i tarptautine darbo aplinkos prigimtị ligoninèje yra didele komunikacinių trikdžių tikimybè. Atskiriems asmenimis ar darbo grupèms iš skirtingų kultūrų gali atsirasti problemu ligoninès valdymo ar klinikinèje aplinkoje. Nepanašūs arba net priešingi skirtingų kultūru požymiai tokiose srityse kaip galios distancija ir kolektyvizmas galètu sukurti nepalankia aplinka veiksmingam komandiniam darbui, darbuotoju atsakomybei/ atskaitomybei ar kokybes gerinimui valdymo ar klinikinès veiklos srityse.

Straipsnyje pateikiamos pastabos ir išvados dèl daugiakultūrès ir daugiakalbès Centrinio Bruklino (Central Brooklyn) ligoninès veiklos.

Reikšminiai žodžiai: užsienyje gimę sveikatos priežiūros darbuotojai, užsienyje apmokyti sveikatos priežiūros darbuotojai, ligoninès darbuotojai, kokybès gerinimas. 